Department of Genetics, Institute of Biosciences

Federal University of Rio Grande do Sul, Porto Alegre, RS, Brazil

\title{
NEW STUDIES ON THE HERITABILITY OF ANTHROPOMETRIC CHARACTERISTIGS AS ASGERTAINED FROM TWINS
}

\author{
F.J. DA ROGHA, F.M. SALZANO, HELOISA F. PENA \\ SIDIA M. CALLEGARI
}

\begin{abstract}
SUMmary
Sixteen anthropometric measurements were performed on each of $4^{8} \mathrm{MZ}$ and $5 \mathrm{I}$ DZ adult twin pairs. The largest amount of diversity between $\mathrm{MZ}$ and $\mathrm{DZ}$ was observed in relation to stature which was in average about three-and-a half times more different in the latter. Forehead and nasal height were also three times more variable among DZ twins, while head and nasal breadth, morphological face height, and lip thickness were twice as variable. The heritability estimates and $F$ ratios yielded significant values in both sexes for twelve traits. The exceptions were mandibular and minimum frontal breadth, calf and chest circumference. The largest heritabilities were observed for stature, head breadth and lip thickness. Correlation matrices were obtained for all measurements; those showing significantly positive coefficients, however, did not show similar heritability values.
\end{abstract}

Despite some discussion about their usefulness, anthropometric measurements continue to be performed in human biological studies and formal recommendations have been given about their use in the assessment of the biological distance between populations (WHO I 968 , Weiner and Lourie 1969). It is clear that for such purposes characteristics which are as little as possible influenced by the environment should be preferred. Unfortunately, studies specifically designed to obtain heritability estimates of these traits are few, and the numbers of individuals measured small (reviews in Vandenberg 1962, Conterio and Chiarelli ig62). Since a given character can have different heritabilities in varied environments it is also important that estimates obtained in a given place or population are not uncritically extrapolated to another group. Therefore, anthropometric measurements were obtained as a part of a more general investigation dealing with a series of $M Z$ and $D Z$ twins studied in Porto Alegre, Brazil, in order to obtain new heritability estimates of these traits. Since many of these measurements do not vary independently, correlation coefficients between them were calculated to verify if these heritability values were of the same order of magnitude in the highly correlated characters, thus providing a check on the method and possible sampling problems. 


\section{MATERIALS AND METHODS}

The great majority of the subjects studied live in Porto Alegre, RS, Brazil. Two male DZ pairs, however, were from the nearby cities of Esteio and Canoas. The localization of the series was made primarily through inquiries at high-schools; but information obtained from the twins thus ascertained about other pairs, and other informants were also utilized.

The mean age of the female MZ twins was 2 I and those of the other categories 19 years. Most of them were in the age interval of ${ }_{1} 3^{-2} 6$; none was younger than 13 years. One $M Z$ female and two DZ male pairs were classified as Negroid, all others being White.

Zygosity diagnosis was made using blood groups $\mathrm{A}_{1} \mathrm{~A}_{2} \mathrm{BO}, \mathrm{Rh}$ (tests with anti-C, $\mathrm{C}^{w}$, -c, -D, -E, -e), MNSs, P, Duffy, and Kell; ABH secretion; and serum haptoglobins. Tests for color-blindness were also performed, but none of the twins proved to be deficient. Standardized photographs and dermatoglyphics were obtained as well, but were not considered in the final decision about zygosity. A pair was considered DZ if it presented any difference in the above mentioned genetic markers. The probability of dizygosity in the twins concordant for all of them varied from 2 to $6 \%$. However, it should be noted that only in relation to one pair there was doubt about the classification made, and in this case the inclusion of dermatoglyphic traits in the probability estimates strengthened the classification based on monogenic characteristics.

Details about how the measures were taken and the tests done to verify the measuring error are given in Da Rocha (I97I) and Da Rocha and Salzano (I972). The data were transferred to punched cards and all calculations performed by a I I 30 IBM electronic computer of the Data Processing Center of our University.

\section{RESULTS}

Tables I and II show the averages, standard deviations and coefficients of variability for the sixteen measurements taken. As can be seen, there are no significant differences between $\mathrm{MZ}$ and $\mathrm{DZ}$ twins, either in relation to the averages or the between-pair variability. The values are those expected for a young Caucasian population.

The average intrapair differences in these measurements are shown in Table III. The largest amount of diversity between DZ and MZ was found in relation to stature which as an average was about 3.5 times more different in the former. Forehead and nasal height were also about three times more variable among DZ twins, while head and nasal breadth, morphological face height and lip thickness were twice as variable.

The results concerning weight are worth commenting on because of two undoubtedly MZ pairs who showed differences of 21.5 and $25.5 \mathrm{~kg}$, respectively. In relation to those who showed the greatest difference, we know that the reason for it was an intensive dietary treatment undergone by one of the twins. Omitting these two pairs, the MZ average difference for weight is reduced by half.

Correlation matrices were obtained for all measurements. The most meaningful comparisons are presented in Tables IV, V, and VI. Correlations between stature, 
TABle I

Anthropometric Measurements of the Porto Alegre Male Twin Series

\begin{tabular}{|c|c|c|c|c|c|c|}
\hline \multirow{2}{*}{ Characteristic } & \multicolumn{3}{|c|}{$\mathrm{MZ}$ pairs $(\mathrm{N}=2 \mathrm{I})$} & \multicolumn{3}{|c|}{ DZ pairs $(\mathrm{N}=22)$} \\
\hline & Mean & $S D$ & $C V$ & Mean & $S D$ & $C V$ \\
\hline Stature & I $69 \cdot 3$ & 7.8 & 4.6 & 171.6 & $5 \cdot 1$ & 3.0 \\
\hline Weight & 6.3 & 12.6 & 20.6 & $5^{8.4}$ & 7.1 & I 2.2 \\
\hline Head length & 19.2 & 0.6 & $3 \cdot I$ & 19.0 & 0.7 & $3 \cdot 7$ \\
\hline Head breadth & 15.0 & 0.6 & 4.0 & 14.9 & 0.6 & 4.0 \\
\hline Bizygomatic breadth & I 3.6 & 0.7 & 5.1 & 13.5 & 0.5 & $3 \cdot 7$ \\
\hline Bigonial & 10.3 & 0.7 & 6.8 & 10.3 & 0.4 & $3 \cdot 9$ \\
\hline Forehead height & 6.7 & 0.7 & 10.4 & 6.7 & 0.5 & $7 \cdot 5$ \\
\hline Morphol. face height & I 1.8 & 0.5 & 4.2 & 11.9 & 0.7 & $5 \cdot 9$ \\
\hline Nasal height & 4.9 & 0.4 & 8.2 & $5 \cdot 1$ & 0.3 & $5 \cdot 9$ \\
\hline Nasal breadth & 3.6 & 0.3 & 8.3 & $3 \cdot 4$ & 0.3 & 8.8 \\
\hline Lip thickness & 1.7 & 0.3 & 17.6 & 1.7 & 0.3 & I 7.6 \\
\hline Sitting height & 85.9 & $4 \cdot 5$ & 5.2 & 87.2 & 3.5 & 4.0 \\
\hline Calf circumference & 35.2 & $3 \cdot 4$ & $9 \cdot 7$ & $34 \cdot 3$ & 2.4 & 7.0 \\
\hline Chest circurrference & 85.2 & 6.4 & $7 \cdot 5$ & 86. I & $5 \cdot 4$ & 6.3 \\
\hline Head circumference & $55 \cdot 3$ & 1.6 & 2.9 & $54 \cdot 9$ & 1.5 & 2.7 \\
\hline Minimum frontal breadth & 11.9 & 0.6 & 5.0 & I 1.9 & $0 . \overline{6}$ & 5.0 \\
\hline
\end{tabular}

Nott. Measurements in cm, weight in $\mathrm{kg}$. Among the MZ's, due to a registration problem, data are not available for the calf, chest, and head circumferences of one pair.

$C V=$ coefficient of variability.

TABLE II

Anthropometric Measurements of the Porto Alegre Female Twin Series

\begin{tabular}{|c|c|c|c|c|c|c|c|}
\hline \multirow{2}{*}{ Characteristic } & \multicolumn{3}{|c|}{$\mathrm{MZ}$ pairs $(\mathrm{N}=27)$} & \multicolumn{4}{|c|}{$\mathrm{DZ}$ pairs $(\mathrm{N}=29)$} \\
\hline & Mean & $S D$ & $C V$ & Mean & $S D$ & & $C V$ \\
\hline Stature & I $5^{8 .}$ I & 6.0 & 3.8 & $159 \cdot 5$ & $5 \cdot 4$ & & $3 \cdot 4$ \\
\hline Weight & $49 \cdot 5$ & 6.6 & I $3 \cdot 3$ & 51.5 & 8.3 & & 16.1 \\
\hline Head length & 18.1 & 0.6 & $3 \cdot 3$ & I 8.3 & 0.5 & & 2.7 \\
\hline Head breadth & 14.4 & 0.5 & $3 \cdot 5$ & I 4.5 & 0.6 & & 4. I \\
\hline Bizygomatic breadth & 12.9 & 0.4 & 3.1 & I $3 . \mathrm{I}$ & 0.5 & & 3.8 \\
\hline Bigonial & 9.8 & 0.4 & $4 \cdot 1$ & $9 \cdot 9$ & 0.6 & & 6.1 \\
\hline Forehead height & 6.3 & 0.6 & $9 \cdot 5$ & 6.5 & 0.5 & & 7.7 \\
\hline Morphol. face height & 1 0.8 & 0.6 & 5.6 & I I.I & 0.6 & & $5 \cdot 4$ \\
\hline Nasal height & $4 \cdot 5$ & 0.3 & 6.7 & 4.6 & 0.3 & & 6.5 \\
\hline Nasal breadth & 3.1 & 0.2 & 6.4 & 3.2 & 0.3 & & $9 \cdot 4$ \\
\hline Lip thickness & 1.5 & 0.2 & $13 \cdot 3$ & I. 6 & 0.2 & & 12.5 \\
\hline Sitting height & 81.7 & $4 \cdot 4$ & $5 \cdot 4$ & 83.4 & $4 \cdot 5$ & & $5 \cdot 4$ \\
\hline Cialf circumference & 32.1 & 2.0 & 6.2 & 33.2 & 2.7 & & 8.1 \\
\hline Chest circumference & $82 \cdot 3$ & 5.2 & 6.3 & 82.1 & 5.2 & $\therefore$ & 6.3 \\
\hline Head circumference & $53 \cdot 4$ & I. 7 & 3.2 & $54 \cdot 0$ & 1.5 & & 2.8 \\
\hline Minimum frontal breadth & I 1.4 & 0.5 & $4 \cdot 4$ & I I. 6 & 0.6 & & 5.2 \\
\hline
\end{tabular}

Note. Measurements in $\mathrm{cm}$, weight in $\mathrm{kg}$. Among the MZ's, due to a registration problem, data are not available for sitting height and chest circumf $r$ rence of one pair.

$C V=$ coefficient of variability. 
TABLE III

Average Intrapair Differences in Anthropometric Measurements in the Porto Alegre Twin Series

\begin{tabular}{|c|c|c|c|c|}
\hline \multirow{2}{*}{ Characteristic } & \multicolumn{2}{|c|}{ MZ pairs } & \multicolumn{2}{|c|}{$\mathrm{DZ}$ pairs } \\
\hline & $\begin{array}{c}\text { Males } \\
\mathrm{N}=\mathbf{2} \mathbf{I}\end{array}$ & $\begin{array}{l}\text { Females } \\
\mathrm{N}=27\end{array}$ & $\begin{array}{c}\text { Males } \\
\mathrm{N}=22\end{array}$ & $\begin{array}{l}\text { Females } \\
\mathrm{N}=29\end{array}$ \\
\hline Stature & 1.2 & 1.o & 4.1 & 3.9 \\
\hline Weight & $4.8^{\mathrm{a}}$ & 2.5 & 5.6 & 5.6 \\
\hline Head length & 0.3 & 0.2 & 0.5 & 0.4 \\
\hline Head breadth & 0.2 & 0.2 & 0.5 & 0.4 \\
\hline Bizygomatic breadth & 0.2 & 0.2 & 0.3 & 0.3 \\
\hline Bigonial & 0.3 & 0.3 & 0.3 & 0.4 \\
\hline Forehead height & 0.2 & 0.2 & 0.6 & 0.7 \\
\hline Morphol. face height & 0.3 & 0.2 & 0.7 & 0.5 \\
\hline Nasal height & 0.1 & $0 . \mathrm{I}$ & 0.3 & 0.3 \\
\hline Nasal breadth & 0.1 & 0.1 & 0.2 & 0.2 \\
\hline Lip thickness & 0.1 & 0.1 & 0.2 & 0.2 \\
\hline Sitting height & I.I & I.0 & 2.4 & 1.8 \\
\hline Calf circumference & I. 3 & 0.7 & 2.1 & 1.7 \\
\hline Chest circumference & 2.6 & 2.4 & 4.4 & 4.0 \\
\hline Head circumference & 0.9 & $0.9^{\mathrm{b}}$ & 1.4 & 0.9 \\
\hline Minimum frontal breadth & 0.3 & 0.2 & 0.3 & 0.5 \\
\hline
\end{tabular}

See footnotes to Tables I and II.

a The exclusion of two aberrant pairs (with differences of 21.5 and $25.5 \mathrm{~kg}$ respectively) lowers this average to $2.3 \mathrm{~kg}$.

b The exclusion of one aberrant pair, in whom there must have been a mistake in the registration of this measure (no appreciable differences were recorded in head length or head breadth) lowers this average to 0.6

TABLE IV

Correlation Between Measures of Length and Mass

\begin{tabular}{lllllr}
\hline \hline & & $\begin{array}{c}\text { Sitting } \\
\text { height }\end{array}$ & Weight & $\begin{array}{c}\text { Chest } \\
\text { circumference }\end{array}$ & $\begin{array}{c}\text { Calf } \\
\text { circumference }\end{array}$ \\
\hline Stature & M-MZ & $0.64^{* *}$ & 0.38 & $0.1^{*}$ & 0.20 \\
& M-DZ & $0.4^{*}$ & $0.4^{1}$ & 0.10 & -0.01 \\
& F-MZ & $0.67^{* * *}$ & $0.45^{*}$ & 0.20 & 0.04 \\
Sitting & F-DZ & $0.73^{* * *}$ & 0.17 & 0.04 & -0.01 \\
height & M-MZ & & 0.29 & 0.20 & 0.10 \\
& M-DZ & & 0.27 & 0.16 & -0.19 \\
Weight & F-MZ & & 0.26 & -0.02 & -0.06 \\
& F-DZ & & 0.26 & 0.04 & 0.13 \\
& M-MZ & & & $0.90^{* * *}$ & $0.89^{* * *}$ \\
& F-MZ & & & $0.79^{* * *}$ & $0.6^{* *}$ \\
Chest & F-DZ & & & $0.86^{* * *}$ & $0.75^{* * *}$ \\
circumference & M-MZ & & & $0.82^{* * *}$ & $0.88^{* * *}$ \\
& M-DZ & & & & $0.78^{* * *}$ \\
& F-MZ & & & & $0.8^{* * *}$ \\
& F-DZ & & & & $0.58^{* * *}$ \\
& & & & & $0.67^{* * *}$ \\
\hline
\end{tabular}

See footnotes to Tables I and II. 
sitting height, weight, chest circumference, and calf circumference are shown in Table IV. If we consider four subsamples (male DZ, female DZ, male MZ, and female MZ), it is possible to obtain 40 correlation coefficients. Of these, I 7 were significant (at the 5, I, and o.I\% levels.) As expected, sitting height is correlated with stature, while chest and calf circumference show a reciprocal relation and are highly correlated with weight.

Table $\mathrm{V}$ presents similar comparisons for bizygomatic, mandibular (bigonial), nasal, minimum frontal, and head breadth. The nasal measurement does not correlate in a consistent way with the others, but the four remaining measures are highly intercorrelated, suggesting a common factor for facial and head breadth.

Table $\mathrm{V}$

Correlation Between Measures of Facial and Head Breadth

\begin{tabular}{|c|c|c|c|c|c|}
\hline & & Bigonial & $\begin{array}{c}\text { Nasal } \\
\text { breadth }\end{array}$ & $\begin{array}{l}\text { Minimum } \\
\text { frontal } \\
\text { breadth }\end{array}$ & $\begin{array}{l}\text { Head } \\
\text { breadth }\end{array}$ \\
\hline Bizygomatic & $M-M Z$ & $0.77^{* * *}$ & $0.57^{* *}$ & $0.79^{* * *}$ & $0.88 * * *$ \\
\hline \multirow{3}{*}{ breadth } & $\mathrm{M}-\mathrm{DZ}$ & $0.57^{* *}$ & 0.29 & $0.34^{*}$ & $0.40^{*}$ \\
\hline & F-MZ & $0.5^{8 * *}$ & 0.16 & $0.59 * *$ & $0.79 * * *$ \\
\hline & F-DZ & $0.62 * * *$ & $0.3^{2}$ & $0.5 \mathrm{I} *$ & $0.4^{*}$ \\
\hline \multirow[t]{4}{*}{ Bigonial } & $\mathrm{M}-\mathrm{MZ}$ & & $0.54^{* *}$ & $0.73 * * *$ & $0.74 * * *$ \\
\hline & M-DZ & & 0.28 & $0.5^{8 * *}$ & $0.39^{*}$ \\
\hline & $\mathrm{F}-\mathrm{MZ}$ & & -0.12 & $0.47^{*}$ & $0.47^{*}$ \\
\hline & F-DZ & & $0.46^{*}$ & 0.31 & $0.50^{*}$ \\
\hline Nasal & M-MZ & & & $0.37^{*}$ & $0.68 * * *$ \\
\hline \multirow[t]{3}{*}{ breadth } & M-D7 & & & -0.02 & 0.08 \\
\hline & F-MZ & & & 0.07 & o. 16 \\
\hline & F-DZ & & & 0.27 & 0.27 \\
\hline Minimum & $\mathbf{M}-\mathbf{M} Z$ & & & & $0.73^{* * *}$ \\
\hline frontal & M-DZ & & & & 0.3 I \\
\hline \multirow[t]{2}{*}{ breadth } & $\mathrm{F}-\mathrm{MZ}$ & & & & $0.63 * * *$ \\
\hline & F-DZ & & & & 0.27 \\
\hline
\end{tabular}

See footnotes to Tables I and II.

Forehead, nasal, and morphological face height are compared in Table VI. Consistent significant correlations were obtained for nasal and morphological face height only, suggesting relatively independent ontogenetic factors acting in the upper and lower regions of the head.

The intraclass correlation coefficients calculated for the sixteen measurements made in the MZ and DZ twins are presented in Table VII. If the inheritance of these traits is conditioned by many genes with additive action and little environmental effects, one would expect a correlation of about $\mathrm{I} .00$ in $\mathrm{MZ}$ and of 0.50 in DZ. Coefficients above 0.90 were obtained in $M Z$ (both sexes) for stature, sitting height and head breadth. In this class of twins all the $r$ 's calculated showed values above 0.50 , 
TABLE VI

Correlation Between Different Measures of Height in the Head

\begin{tabular}{llcr}
\hline \hline & & $\begin{array}{c}\text { Morphological } \\
\text { face height }\end{array}$ & Forehead height \\
\hline \multirow{2}{*}{ Nasal height } & M-MZ & $0.4^{*}$ & -0.11 \\
& M-DZ & $0.6^{*}$ & -0.21 \\
& F-MZ & $0.50^{* *}$ & 0.12 \\
Morphological face height & F-DZ & 0.33 & $0.4^{*}$ \\
& M-MZ & & 0.01 \\
& M-DZ & & 0.13 \\
& F-MZ & & 0.09 \\
& F-DZ & 0.18 \\
\hline
\end{tabular}

See footnotes to Tables I and II.

TABLE VII

Intraclass Correlation Coefficient for Anthropometric Measurements in the Porto Alegre Twin Series

\begin{tabular}{|c|c|c|c|c|}
\hline \multirow{3}{*}{ Characteristic } & \multicolumn{4}{|c|}{ Correlation coefficient $(r)$} \\
\hline & \multicolumn{2}{|c|}{ Male pairs } & \multicolumn{2}{|c|}{ Female pairs } \\
\hline & $\mathrm{MZ}(\mathrm{N}=2 \mathrm{I})$ & $\mathrm{DZ}(\mathrm{N}=22)$ & $\mathrm{MZ}(\mathrm{N}=27)$ & $\mathrm{DZ}(\mathrm{N}=29)$ \\
\hline Stature & 0.97 & 0.42 & 0.98 & 0.63 \\
\hline Weight & $0.8 \mathrm{I}^{\mathrm{a}}$ & 0.4 & 0.89 & 0.65 \\
\hline Head length & 0.77 & 0.49 & 0.93 & $0.4^{8}$ \\
\hline Head breadth & $0.9^{2}$ & 0.34 & 0.90 & 0.44 \\
\hline Bizygomatic breadth & 0.92 & 0.55 & $0.8_{5}$ & 0.68 \\
\hline Bigonial & $0.7^{\mathrm{a}}$ & $0.5^{8}$ & 0.60 & 0.56 \\
\hline Forehead height & 0.87 & 0.00 & $0.8_{7}$ & $0.3 \mathrm{I}$ \\
\hline Morphol. face height & 0.57 & 0.25 & 0.88 & 0.49 \\
\hline Nasal height & 0.83 & 0.28 & 0.74 & 0.54 \\
\hline Nasal breadth & 0.80 & 0.18 & 0.65 & 0.55 \\
\hline Lip thickness & 0.95 & $0.6_{5}$ & 0.87 & $0.4^{8}$ \\
\hline Sitting height & 0.95 & 0.65 & 0.94 & 0.86 \\
\hline Calf circumference & $0.8_{3}$ & 0.46 & $0.8_{5}$ & 0.72 \\
\hline Chest circumference & 0.82 & 0.43 & 0.77 & 0.64 \\
\hline Head circumference & 0.77 & 0.28 & $0.3^{8 b}$ & 0.63 \\
\hline Minimum frontal breadth & 0.77 & 0.63 & $0.8 \mathrm{I}$ & 0.43 \\
\hline
\end{tabular}

See footnotes to Tables I and II.

a Exclusion of the two aberrant pairs already mentioned in Table III increases these values to 0.97 for weight and 0.82 for bigonial.

b Exclusion of the aberrant pair already mentioned in Table III increases this value to o.99. 
with one exception (head circumference among the females) that may be due to a mistake in the registration of the data. The distribution among DZ is more scattered; many coefficients are centered around $0.5^{\circ}$; it is noteworthy, however, that among the DZ females about two-thirds presented higher correlations.

Table VIII shows the heritability estimates and $F$ ratios calculated for the sixteen measurements obtained in the Porto Alegre twin series. Twelve of the sixteen traits

TABLE VIII

Heritability Estimates $\left(h^{2}\right)$ and $F$ Ratios of Anthropometric Measurements in the Porto Alegre Twin Series

\begin{tabular}{|c|c|c|c|c|}
\hline \multirow{2}{*}{ Characteristic } & \multicolumn{2}{|c|}{ Male pairs $(N=43)$} & \multicolumn{2}{|c|}{ Female pairs $\left(\mathrm{N}=5^{6}\right)$} \\
\hline & $h^{2}$ & $F$ & $h^{2}$ & $F$ \\
\hline Stature & 0.90 & $9 \cdot 76 * * *$ & 0.92 & $12.65^{* * *}$ \\
\hline Weight & 0.85 & $6.86 * * *$ & $0.8 \mathrm{I}$ & $5.10 * * *$ \\
\hline Head lenght & 0.63 & $2.68 *$ & 0.79 & $4 \cdot 77^{* * *}$ \\
\hline Head breadth & 0.86 & $8.50^{* * *}$ & 0.90 & $10.00 * * *$ \\
\hline Bizygomatic breadth & 0.63 & $2.68 *$ & 0.71 & $3 \cdot 50^{* *}$ \\
\hline Bigonial & 0.00 & 0.00 & 0.45 & 1.81 \\
\hline Forehead height & 0.79 & $4 \cdot 72 * * *$ & 0.74 & $3.86 * *$ \\
\hline Morphol. face height & 0.71 & $3.45^{* *}$ & 0.76 & $4.13^{* * *}$ \\
\hline Nasal height & 0.70 & $3 \cdot 3^{8 * *}$ & 0.67 & $3.00 * *$ \\
\hline Nasal breadth & 0.83 & $5.6 \mathrm{I} * * *$ & 0.64 & $2.77^{*}$ \\
\hline Lip thickness & $0.9^{2}$ & I $3.00 * * *$ & 0.74 & $3.87 * *$ \\
\hline Sitting height & 0.77 & $4.29^{* * *}$ & 0.60 & $2.5^{\circ} *$ \\
\hline Calf circumference & 0.21 & 2.25 & $0.7 \mathrm{I}$ & $3 \cdot 5^{\circ * *}$ \\
\hline Chest circumference & 0.16 & 2.25 & 0.36 & I. 56 \\
\hline Head circumference & 0.64 & $2.77^{*}$ & 0.59 & $2.4^{*}$ \\
\hline Minimum frontal breadth & 0.13 & I. 45 & 0.80 & $5.10 * * *$ \\
\hline
\end{tabular}

Notes. See footnotes to Tables I and II.

The two male MZ pairs aberrant for weight and bigonial (see Tables III and VII) and the one female $\mathrm{MZ}$ pair aberrant for head circumference were not included in the calculations involving these measures.

yielded significant values in both sexes. The exceptions were mandibular (bigonial) and minimum frontal breadth, calf and chest circumference. Probably due to sampling problems, the within variance of $\mathrm{MZ}$ pairs for mandibular breadth proved to be of about the same order of magnitude as that of the DZ pairs, leading to a $h^{2}$ estimate of zero. On the other side of the scale, the measurements which showed the largest heritabilities were stature (0.90 and 0.92 among males and females, respectively), head breadth ( 0.86 and 0.90 ), and lip thickness ( 0.92 and 0.74 ).

Comparison of the heritability values observed for the traits that showed correlation indicates that only for morphological facial and nasal height the estimates are similar. They have a correlation of about $0.5^{\circ}$ and the $h^{2}$ is equal to $0.7^{1}$ and $0.7^{\circ}$ in males and 0.76 and 0.67 in females, respectively. Widely different heritability 
values were observed, on the other hand, for mandibular and head breadth, for instance ( 0.00 and 0.86 in males, 0.45 and 0.90 in females), which showed about the same degree of correlation $(0.50)$ as the other measurements mentioned.

\section{DISCUSSION}

Despite some limitations the twin method has been widely used in human genetics, since on many occasions it can provide data which are decisive for the evaluation of the effects of the environment in a given trait. Care should be taken when using the method especially in relation to the following points: $(a)$ The twin sample should be as representative as possible of the population from which it was drawn; $(b)$ the $\mathrm{MZ}$ and $\mathrm{DZ}$ pairs should be matched in relation to all other variables besides those under study, to avoid extraneous influences; $(c)$ the zygosity determination should be objectively established; $(d)$ in characteristics like the anthropometric ones, that vary with sex, age and for which mating may be nonrandom, these additional sources of variation should be considered in the analysis of data collected by different investigators. In this regard, it should be emphasized that the four categories into which our sample was divided (MZ, males and females; DZ, males and females) present about the same mean age, no significant differences being observed between $M Z$ and $\mathrm{DZ}$ paris in relation to the averages of the characteristics measured or of their between-pair variabilities, and that the values found are those to be expected for a young Caucasian population. The zygosity determination was made using a good battery of well-established genetic markers.

In traits that are liable to environmental modification, a particular set of circumstances may sometimes completely change a given heritability estimate, especially if the sample sizes are not large. This can be exemplified by the high differences in weight that we observed between two pairs of $\mathrm{MZ}$ twins (see comments in Tables III and VII). We know that in one case this was due to an intensive dietary treatment undergone by only one member of the pair. It is quite possible that these twins may show a closer resemblance if tested again, either because the twin under treatment stopped it or because the cotwin also decided to control his food intake.

As was indicated above, when dealing with anthropometric traits we should be careful in comparing results from different researchers. If we consider all the sources of variation that may be present in these inter-series comparisons, however, the general impression is that they agree reasonably well among themselves. Starting with the question of the correlation between traits, we see that our values are of the same order of magnitude as those obtained by Vassal and Pineau (I958) among French soldiers or those observed by Pollitzer et al. (I970) in a sample of Seminole Indians from Florida, USA. The exceptions are the correlations between bigonial and minimum frontal breadth, and between the former and head breadth, our estimates being larger than those obtained by the French authors. As for the heritabilities and $F$ values, the seven series listed by Vandenberg ( 1962 ) and Conterio and Chiarelli 
( 1962 ) also show results that in a general way are in accordance with our data. Thirteen characteristics could be compared and for only two of them the $F$ 's calculated here showed significant deviations from those obtained by the majority of other authors: our values for head breadth are higher and those for bigonial lower than those generally obtained in the other series.

Our attempt to disclose similar patterns of heritability in traits that are intercorrelated failed. This is an indication that these correlations may be mainly phenotypic, the genotypic control of these traits being exercised independently. Sampling problems that might arise either in the estimation of the correlation coefficients or in the heritability calculations may however distort the true relationships. Further studies along these lines using more extensive family and twin material are worth undertaking.

Acknowledgements. We thank G. V. Simões for help in many phases of this investigation. Our researches are supported by the Câmara Especial de Pós-graduação e Pesquisa da Universidade Federal do Rio Grande do Sul, Conselho Nacional de Pesquisas, Coordenação do Aperfeiçoamento do Pessoal de Nível Superior and Fundaçào de Amparo à Pesquisa do Estado do Rio Grande do Sul.

\section{REFERENGES}

Conterio F., Chiarelli B. 1962. Studio sulla ereditabilità di alcuni caratteri antropometrici misurati sui gemelli. Ateneo Parmense, 33 (Suppl. I): I $10-1$ I 6.

Da Rocha F.J. I97I. Antropometria em Indígenas Brasileiros. Departamento de Genética, Universidade Federal do Rio Grande do Sul, Publ. 2: I - I 10.

Da Rocha F.J., Salzano F.M. 1972. Anthropometric studies in Brazilian Cayapo Indians. Am. J. Phys. Anthropol., 36: 95-102.

Pollitzer W.S., Rucknagel D., Tashian R., Shreffler D.C., Leyshon W.C., Namboodiri K., Elston R.C. 1970. The Seminole Indians of Florida: morphology and serology. Am. J. Phys. Anthropol., $32: 65-82$.

Vandenberg S.G. I962. How "stable" are heritability estimates? A comparison of heritability estimates from six anthropometric studies. Am. J. Phys. Anthropol., 20: 331-338.

Vassal P., Pineau H. I958. Les variations des diamètres céphaliques chez le jeune adulte français; étude statistique. Bull. Mem. Soc. Anthropol. Paris, 9: 93-1 24.

Weiner J.S., Lourie J.A. 1969. Human Biology. A Guide to Field Methods. Blackwell, Oxford.

WHO (1968). Research on human population genetics. Wld. Hlth. Org. Techn. Rep. Ser, $3^{87}: \mathbf{I}-3^{2}$.

Riassunto

Sono state eseguite sedici misurazioni antropometriche su 99 coppie gemellari adulte, 48 MZ e 5 I DZ. La massima differenza è stata riscontrata per la statura, circa tre volte e mezzo più discordante nei DZ che nei MZ. L'altezza frontale e quella nasale sono risultate tre volte più discordanti nei DZ rispetto ai MZ, mentre la larghezza del cranio e quella del naso, l'altezza facciale e lo spessore delle labbra, solo due volte. Le stime di ereditarietà e di $F$ hanno dato valori significativi in ambedue i sessi per dodici caratteri. Hanno fatto eccezione la larghezza mandibolare, la larghezza minima frontale, la circonferenza del polpaccio e la circonferenza toracica. I valori di ereditarietà più elevati sono stati osservati per la statura, la larghezza cranica e lo spessore delle labbra. Per tutte le misurazioni sono state ricavate matrici di correlazione; tuttavia, quelle che presentavano coefficienti significativamente positivi non hanno presentato valori di ereditarietà simili. 
RÉSUMÉ

Seize mensurations anthropometriques ont été effectuées chez 99 couples de jumeaux adultes, 48 MZ et 5 I DZ. La discordance était de trois fois et demi plus élevée chez les DZ par rapport aux MZ pour la taille, de trois fois pour la hauteur frontale et nasale, et de deux fois pur la largeur du crâne et du nez, la hauteur faciale et l'épaisseur des lèvres. Les estimes d'hérédité et de $F$ ont donné des valeurs significatives dans les deux sexes pour douze mensurations, les exceptions étant constituées par la largeur mandibulaire, la largeur frontale, la circonférence thoracique et du mollet. Les valeurs d'hérédité les plus élevées ont été trouvées pour la taille, la largeur du crâne et l'épaisseur des lèvres. Pour toutes les mensurations, des index de corrélation ont été calculés; toutefois les mensurations présentant une corrélation significativement positive n'ont pas également présenté de valeurs d'hérédité similaires.

\section{ZUSAMMENFASSUNG}

An 99 erwachsenen Zwillingspaaren (48 EZ und $5^{1} \mathrm{ZZ}$ ) wurden sechzehn anthropometrische Messungen vorgenommen. Der grösste Unterschied wurde bei der Statur festgestellt, bei der die Diskordanz der ZZ dreieinhalb mal so gross ist wie bei den EZ. Die Diskordanz der ZZ in der Stirn- und Nasenhöhe war drei mal so gross wie bei EZ, während das Verhältnis bei Messung der Schädel- und Nasenbreite, der Gesichtshöhe und Lippenbreite nur 2 : I betrug. Erblichkeits- und F-Messungen ergab bei beiden Geschlechtern bei zwölf Merkmalen recht bedeutende Ergebnisse. Eine Ausnahme stellten die Kieferbreite, die Mindeststirnbreite, Wadenund Brustumfang dar. Die höchsten Werte der Erblichkeit wurden bei der Statur, der Schädelbreite und der Lippenbreite beobachtet. Für alle Messungen wurden Korrelations-inatritzen aufgestellt; es zeigte sich jedoch, dass in den Fällen, in denen die Koeffiziente deutlich positiv waren, die Erblichkeitswerte dem nicht entsprachen.

Dr. Francisco M. Salzano, Departamento de Genética, Universidade Federal do Rio Grande do Sul, Caixa Postal 1953, 900oo Porto Alegre, RS, Brazil. 